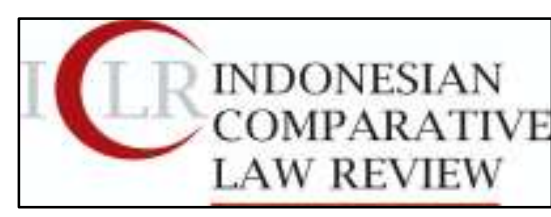

Volume 1 No 2, June 2019

P-ISSN: 2655-2353, E-ISSN: 2655-6545
Article Info:

Received : $12-07-2019$

Revised : :20-08-2019

Accepted : $23-08-2019$

\title{
Development of Land Conflict Settlement Model Based on Indigenous Knowledge of the Local Communities in Indonesia
}

\author{
Sunarno \\ Faculty of Law, Universitas Muhammadiyah Yogyakarta \\ E-mail: sunarno@umy.ac.id
}

\begin{abstract}
Land conflict has become a classic issue in Indonesia and an effective dispute settlement seems to be urgent. The study aims at evaluating the possibility to incorporate the indigenous knowledge of the local communities in land dispute settlement system. This socio-legal research employs both qualitative and quantitative approach. It is found that the current legal and institutional systems are not in accordance with the legal consciousness of the Indonesian society. The purposes of agrarian policy have promoted the domination of the state over the people's rights. The policies were made to safeguard the interests of elite and its supporters and at the same times ignore the society interests. As the old model of land dispute settlement, the Dutch procedural law (HIR) served the colonial interest. In fact, there are statutory provisions in land and natural resources sector regulating land dispute settlement that accommodate the local wisdom. In addition, article 18 of the 1945 Constitution and Article 5 of the Basic Agrarian Law explicitly recognize the capacity of the indigenous people in settling land dispute. However, it needs further elaboration and institutionalization of their values. A model of legal system that incorporate the customary values should be developed. The Indonesian customary legal system rests on the concept of regional values that exist throughout Indonesia regions.
\end{abstract}

Keywords: land disputes, settlement local community wisdom, customary legal system.

\section{A. Introduction}

Various reports indicate the issue of land and justice as the most corrupt and complex sector of the problem 1 . Thirty percent $(30 \%)$ of the total cases that enter the court are of the land sector. 500 from a total of 2000 complaints that went to Human Rights Commission (KOMNAS HAM), and 25 percent of the total complaints that were submitted to the Indonesian Ombudsman Institute are also about land cases. In addition, interventions through security and military approaches often occur so that more violent clashes between the government and civil society are inevitable. ${ }^{2}$ Land conflicts have exposed the members of the society not only to the loss of their lands but even their lives. It is still fresh in the memory of the society of more than 10 fatalities in Mesuji, Lampung and land cases in Bima, NTB. This clearly illustrates that the land problem will

1Jacqueline Martin \& Chris Turner, 2004, Unlocking Law, Judith Bray, Series editors p.231

${ }^{2}$ Hakim Garuda Nusantara, 2006, Tanah untuk Rakyat, Paper, International conference, Komnas HAM, p.67 
continue to be turbulent and may even be able to drive a social revolution. ${ }^{3}$

Various anticipatory measures and control of land dispute resolution have been carried out by various parties. The House of People Assembly (MPR), particularly the Government, and the House of People Representative (DPR) are in the midst of fixing the land regulatory system and establishing an institutional land settlement system. MPR Decree Number IX of 2000 on Agrarian Reform is expected to inspire radical change. Law Number 2 of 2012 is also assumed to be an effective working foundation for the settlement of land cases. Independent groups such as KOMNAS HAM and various NGOs were established and their roles were optimized in advocating issues in the land sector. What might be said to be a significant movement is the agrarian reform program re-launched by the President which allows people to speak out loudly to the government on various land issue. ${ }^{4}$ However, a number of important notes have been found that the factual land disputes continue to be volatile and in terms of quantity and quality those are increasingly harmful to the life of the nation and state. ${ }^{5}$ This illustrates that the system for resolving land issues has not been effective yet.

The failure to resolve land problems is triggered by the following fundamental factors:

1. Not accommodate many of the fundamental interests of the parties;

2. Short term settlement paradigm;

3. Weak participation among communities;

\footnotetext{
${ }^{3}$ Maria Soemardjono, 2010, "Hukum Pertanahan, dari Regulasi sampai Implementasi”, Kompas Group, p.10100

4See Annual Report on Land National Agent, 2015 edisi1, p.20

${ }^{5}$ Maria Sumardono, Hak Sosial Politik Ekonomi Warga dalam Pertanahan, Kompas Group, 210 p.25
}

4. Unsystematic approach; and

5. The verdict is not effective. 6

Various literatures and practices on land conflict settlement based on the local wisdom illustrate its potential in the development of a legal framework that becomes guidelines and models of land conflict settlement. 7

\section{B. Statement of Problem}

Horizontal and structural land fatalities foster the growth of land disputes. In general, the triggering factor is the large gap between das sollen and das sein in concept, purpose, institution and procedural arrangements regarding land disputes. This research address some questions as follows:

1. What is the current system of land dispute resolution?

2. Which factors that cause the failure in the land dispute resolution?

3. What are the principles of the land dispute resolution model?

This research serves general purposes as follows:

1. To evaluate the applicable land dispute resolution system;

2. To map the failure factors in land conflict settlement;

3.To find new principles as guidelines for the resolution of land conflicts.

\section{Method}

Both qualitative and quantitative method have been employed in addressing the problems. Basically, this research is classified as legal research that combines the nature of non-doctrinal and doctrinal research to get clear research results, comprehensive views,

\footnotetext{
${ }^{6}$ see Nur Fauzi, Pembaharuan Agraria, 2000. KPA, p. 27

${ }^{7}$ See Garth Nettheim, 2002: 200). ADR for Land Matters
} 
systematic thought flow, and significant research findings, so there is a need to use a qualitative approach, especially in analyzing documents relevant legislation, supporting cases, and secondary legal material related to the research topic. Therefore, before conducting empirical research on law and the implementation of the land administration system, it is deemed necessary to explain the general theory and legal framework relating to the research topic.

\section{Result and Analysis}

1. Evaluation on the Gap between Land Policy and the Philosophical Values of Pancasila

The legal system includes the ideals of law, the principles of law, concrete legal methods, legal institutions, and legal consciousness of society.

The values of Pancasila are the highest legal ideals for the Indonesian people. The ideals of a legal nature (Idee des Recht) are to realize justice, certainty and expediency. Justice

Table 1. The following is an illustration of agrarian politics in Indonesia

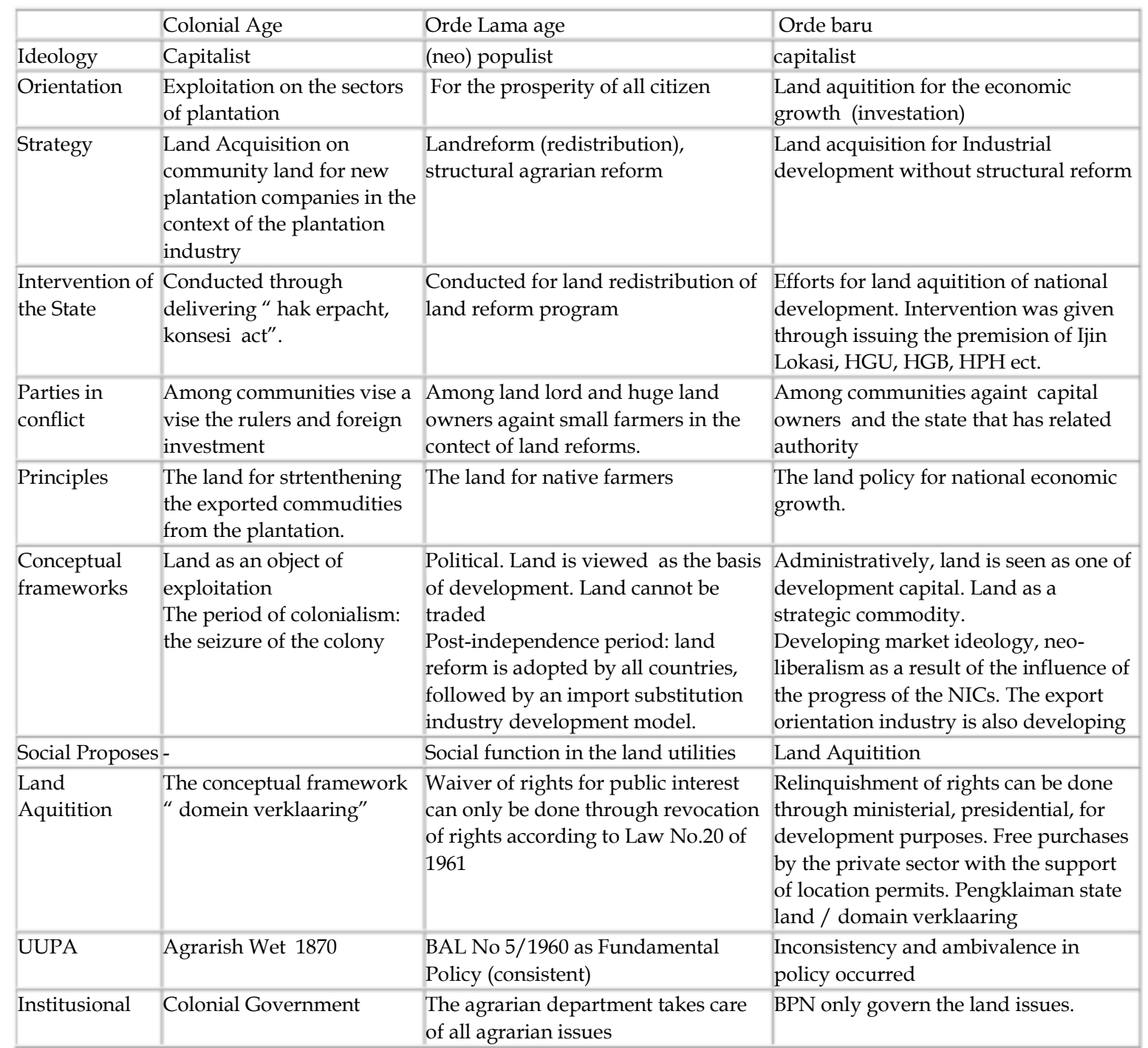

Resources: elaborated and analised from Maria Sumardjono, 2011: 200 -220 
provides the basis on which anyone living in a society can fulfill their basic rights and receive a portion of their work. Certainty provides the basis that the legal system guarantees the existence of human rights. While the purpose of expediency outlines that every citizen can enjoy his rights in accordance with the demands of people's lives.

In reality, law as a political product often blurred to put legal objectives. Justice is limited to discourse, certainty is shackled in complex rules of procedure and bureaucracy, and the use of law is more for the interests of the authorities.

As such, the law seems to become an instrument of the authorities to realize the interests of the authorities themselves, not to respond to the needs of people's lives.

Legal ideals can be categorized into ethical ideals and practical legal ideals. Ethical ideal refers to the upholding of justice in all aspects of human life, while practical ideal refers to the practical needs of humanity in economic, political, and social aspects.

2. Evaluation on the Governance of the Land Dispute Resolution

The national history provides a valuable lesson that the agrarian policy of the colonialist and authoritarian regime was unable to provide any solution for the welfare of society.

As the regime changed, the situation also changed. The Agrarian politic has been interpreted for the interests of developmental ideology through an emphasis on economic growth. Consequently, the patterns of policy in land conflict resolution tended to be authoritarian.
3. Evaluation on the Application of the Responsiveness Principle of Law

The true law constitutes a set of social and political roles that is responsive to the interests of the society. Its character may be populist, responsive, and democratic. ${ }^{8}$ Laws may live and die with the community 9

The law was employed to perpetuate the authorities, as a result, it is blunt upward and sharp downward. This spirit has influenced the bureaucratic system and legal institutional system. So when the law is systemically authoritarian it will be very difficult to change it.

4. Evaluation on the Incorporation of the Professional Principle in the Institution of the Land Dispute Resolution

The idea to develop institutions, including agrarian justice institutions deserves an appreciation. The idea can be translated politically as follows:

a. The form of the implementation of constitutional observance of a democratic rule of law. This institutionalization model is very useful for resolving conflicts (agrarian) through a fair, honest and independent trial.

b. There is a genuine effort to address the empirical problems felt by the wider community with regard to agrarian conflicts.

The new paradigm no longer looks agrarian conflicts as an ordinary problem but an extraordinary problem. Therefore, strategic and comprehensive steps are needed to respond to extraordinary challenges as well as the need for an agrarian justice.

\footnotetext{
${ }^{8}$ See Mahfud, Politik Hukum Indonesia, Gadjah Mada Press, 2000, p.20-27

9Soerjono Soekanto, 199, Penelitian Sosial Djambatan press p.126
} 
Some experts argue that the idea of establishing an agrarian justice is the right and strategic step. It does not only serve the current interest of conflict resolution, but also the future conflict prevention. The
5. The Failure Factors in Incorporating the Principle of Good Governance and Its Indicators

Implementation of land dispute resolution as

Table 2. Indicators of good land governancecan also be elaborated from the governance principle

\begin{tabular}{|c|c|}
\hline Principle & dicators of Go \\
\hline $\begin{array}{l}\text { Legitimacy } \\
\text { cogitimacy, } \\
\text { conformity to law, rule or } \\
\text { principles, rawfullness, } \\
\text { comformity to sound } \\
\text { reasoning }\end{array}$ & $\begin{array}{l}\text { A widely supported legislative and policy framework and documented regulatory } \\
\text { procedures for the administration of private, customary and state landA legislative } \\
\text { framework for management of state land } \\
\text { A continuum of land rights that are legally recognized and protected; and efficiet and } \\
\text { impartial local, administrative and judicial mechanisms to enforce legislation an } \\
\text { resolve dispute }\end{array}$ \\
\hline $\begin{array}{l}\text { Accountability (accountability: } \\
\text { liable to e called to accounts; } \\
\text { responsible to people, for } \\
\text { things }\end{array}$ & $\begin{array}{l}\text { ndat assigning unambiguous institutional responsibility for the land } \\
\text { ervice; } \\
\text { with appropiate oversight by central authority and the community in } \\
\text { ild community tust; } \\
\text { tion mechanism operating in atransparent and predictable manner; } \\
\text { lic expenditure and procurement procedures; } \\
\text { ral resources management; } \\
\text { a service delivery and responsiveness to user needs, satifaction and } \\
\text { ofessional and personal intregity that are enforceable }\end{array}$ \\
\hline $\begin{array}{l}\text { Effectiveness } \\
\text { Effective: concerned with or } \\
\text { having the fuction of } \\
\text { accomplishing or executing }\end{array}$ & $\begin{array}{l}\text { to users in timely and cost-effective manner in } \\
\text {; } \\
\text { sourses most effective use of available resources; }\end{array}$ \\
\hline $\begin{array}{l}\text { Participation } \\
\text { "participation: the action or act } \\
\text { of taking part with others, } \\
\text { spec. The active invorlment of } \\
\text { members of a community or } \\
\text { organizaton in the decisions } \\
\text { which affect them }\end{array}$ & $\begin{array}{l}\text { y to have rights registered in formal or customary system } \\
\text { red; } \\
\text { ited by factors of time, cost, or location }\end{array}$ \\
\hline $\begin{array}{l}\text { Fairness } \\
\text { Fairness: honesty, impartiality, } \\
\text { justice }\end{array}$ & $\begin{array}{l}\text { ll irrespective of status, age, weath, gender, } \\
\text { c; } \\
\text { le can participate; } \\
\text { e safeguards; } \\
\text { ne land administration institution }\end{array}$ \\
\hline
\end{tabular}

Sources: elaborated from Danilo Antonio, 2008: 21-50

ability of the agrarian justice to respond to agrarian conflicts will be greatly influenced by historical-sociological readings on agrarian conflicts and the judiciary itself. part of the governmental administration must be based on the principles of good governance. Without such principles, the resolution of land issues will have a greater failure rate. 10

The principles of good governance have been laid down in Article 20 of the Law 28 of

\footnotetext{
${ }^{10}$ See Maria Sumardjono, Permasalahan Pertanahan, dari Regulasi sampai Implementasi, Kompas Group, 2001. P. 30-35
} 
1999 on State Administration that is Clean and Free from Collusion, Corruption, and Nepotism as follows:

(1) The governmental administration is guided by the general principle of state administration consisting of:

a. principle of legal certainty;

b. the orderly principle of state administration;

c. the principle of public interest;

d. the principle of openness;

e. principle of proportionality;

f. the principle of professionalism;

g. the principle of accountability;

h. principle of efficiency; and

i. the principle of effectiveness.

This general principle is in accordance with the principle of efficiency and the principle of effectiveness.

\section{The Colonial Legacy Factors on the Model of Land Dispute Resolution}

The historical evolution of dispute resolution models in general and land disputes in particular, demonstrates serious efforts to address these problems. After the model of dispute resolution through the courts reached the peak of its authority until the end of the 20th century, then alternative dispute resolution models began to be developed in all countries, regions and lower social units. Although experiencing fluctuations, the background to the presence of alternative dispute resolution can be taken as follows:

a. To reduce the backlog of court cases.

b. To increase community involvement and autonomy in the dispute resolution process

c. To facilitate and expand the access to justice.

d. To develop a high level acceptance of judge decision
7. Evaluation of the Legal Basis for Land Dispute Resolution Model

a. HIR, the procedure law of the Colonial Government, regulate the judges to command the disputing parties resorting to amicable settlement.

b. Law No. 14 of 1970 concerning Judicial Power initiated the emergence of an alternative dispute resolution model. Under this law, Presidential Decree 34 of 1984 concerning the Ratification of the New York Convention on Alternative Dispute Resolution and Arbitration Models

c. Law No. 30 of 1999 concerning Arbitration and Alternative Dispute Resolution offers various alternative methods consisting of: consultation, expert assessment, negotiation, mediation, conciliation, and arbitration.

d. Law No. 4 of 2004 concerning Judicial Power changes the principles of judicial power to accord with the aspirations of judicial reform.

e. Law No. 48 of 2009 concerning Judicial Power reaffirms the use of ADR and arbitration.

In addition, there some other regulations which support the use of ADR methods such as:

a. The Supreme Court Regulation No. 1 of 2008, concerning the application of Peace Deed Agreement (Acta van Dading) including land dispute agreements.

b. Regulation of the Agrarian Minister or the Head of National Land Biro (BPN) Number 1 of 1999 concerning procedures for handling land disputes and conflicts.

c. Regulation of the Head of BPN Number 3 of 2011, concerning the Management and Study of Land Cases.

Besides the laws and regulations above, there are also provisions that are tucked in the laws that are widespread, such as the local government regulation/bylaw and 


\section{8}

\section{Indonesian Comparative Law Review}

several related natural resource laws. More details can be described as follows:

1. The sectors that related to the Agrarian Laws to spell out the matters related to the Law No 5 of 1960 on Basic Agrarian Law are: a. The Law No 52 of 1960 about Land Reform;

b. The Law No. 41 of 2009 about the Protection on the Sustainable Food Farming;

c. The Law No. 2 of 2012 regarding the Procurement of Land for the Implementation of Development in the Public Interest;

d. The Law Regarding Transmigration;

e. The Government Regulation No. 24/97 Land Registration;

f. The Government Regulation No. 60 of 1996 Regarding Land Use

2. Law No. 11 of 1974 on Water Resources, then repealed by Law No. 4 of 2004 on Water Resources. The Act was later revoked by the Constitutional Court.

3. Group of statutory regulations Law Number 4 of 2009, Minerals and Coal

a. PP 23 of 2010, Implementation of the Mining Law;

b. PP 24 of 2011, 1 ${ }^{\text {st }}$ Amendment

c. PP 1 of $2014,2^{\text {nd }}$ Amendment

\section{Evaluation on the Institution Internal Factor: Land Institution}

The institutional existence that runs land management in Indonesia cannot be ignored. Through tracking the history of the institution, it will appear how the ebb and flow of authority of the land agency to date. Based on history, the function of an ideal land institution was reformulated in accordance with the mandate of the 1945 Constitution and the future development of society. The history of the land agency is divided into two periods, namely the first period when it is formed is the Department of Agrarian Affairs, which is then simplified to become the Directorate General, under the Ministry of Home Affairs. The ups and downs of land institutions from Departments, Agencies, Ministries, and back to the Agency are correlated with the ups and downs of authority.

After the issuance of Presidential Regulation No. 10/2006, the institutional and authority of the National Land Agency has been clear, whose position is below and is directly responsible to the President with 21 land functions, nationally, regionally and sectorally.

Institutional structuring of land and diversity needs to be followed by refreshing government officials who are populistminded, wise, strong-minded and solid are certainly the main conditions that will move the National Land Agency of the Republic of Indonesia towards the right direction in accordance with its institutional vision and mission.

Agrarian reform requires national and regional level policies consistently and thoroughly. For this reason, the government's authority in the field of land must be a synergy between central and regional government policies, across sectors and institutions. The government being the authority in the field of land is proportionally obliged to build communication and internal coordination of the government so that land policy runs more effectively and in harmony and smoothly from the central/national, provincial, district / city, to sub-district and village levels. 
Table 3. Implementation of Land Dispute and Conflict Management Activities

\begin{tabular}{|c|c|c|c|c|c|c|}
\hline \multirow[t]{2}{*}{ No. } & \multirow[t]{2}{*}{ City/Region } & \multicolumn{4}{|c|}{ Year } & \multirow[t]{2}{*}{ Total } \\
\hline & & 2016 & 2017 & 2018 & 2019 & \\
\hline 1 & Sleman & 9 & 11 & 11 & 8 & 39 \\
\hline 2 & Bantul & 11 & 24 & 11 & 46 & 92 \\
\hline 3 & Kulonprogo & 2 & 14 & 19 & 13 & 48 \\
\hline 4 & Gunungkidul & 0 & 9 & 0 & 0 & 9 \\
\hline 5 & Yogyakarta & 24 & 19 & 49 & 7 & 99 \\
\hline & Jumlah & 46 & 77 & 50 & 74 & 289 \\
\hline
\end{tabular}

Resources: collected and arranged from community and Provincy Land Agent

Implementation of land management has produced many things as needed by the community. The following are things that are deemed worthy of attention including:

\section{b. Human Resource:}

To improve the employee's competency in accordance with the position it entails requires a standard of education and

Table. 4 Process procedure land dispute governance

\begin{tabular}{|c|c|c|c|}
\hline \multirow[t]{3}{*}{ Plaintif } & \multicolumn{3}{|c|}{ Land Agent } \\
\hline & \multicolumn{2}{|c|}{ Lochet } & \multirow[t]{2}{*}{ Process of service } \\
\hline & Registration & Payment & \\
\hline Plaintif -----------------> & $\begin{array}{l}\text { Receipt of complaints (can } \\
\text { be submitted via the webside } \\
\text { service counter complaint } \\
\text { box) layanan }\end{array}$ & -------------------- $\rightarrow$ & $\begin{array}{l}\text { Processing by related work } \\
\text { units }\end{array}$ \\
\hline Respondest $\leftarrow$--------- & $\begin{array}{l}\text { Submission of the results of } \\
\text { the handling of complaints } \\
\text { and / or responses }\end{array}$ & -1-------- $\rightarrow$ & $\begin{array}{l}\text { Handling complaints and } \\
\text { preparing responses } \\
\text { (Recommendation/solusi }\end{array}$ \\
\hline
\end{tabular}

\section{a. Organization:}

The implementation of the core of the roles of the National Land Agency of the Republic of Indonesia has not been fully effective because there are work units at the regional office level and the land office is not linear with deputies at the central level. Such conditions cause coaching activities to be less effective. Inequality of workload between regions and between work units needs to be reexamined. training that is not currently owned.

Completeness and accuracy of staffing data, as well as improving career patterns are important things that must be done immediately so that employee placement and promotion can run as expected by the organization.

c. Work Facilities and Infrastructure:

Provincial Office of the National Land Agency Special Region of Yogyakarta does not all have adequate infrastructure. There are still land offices that do not yet have good office buildings with decent office building 
standards, and even still stand on the land rights of other parties, so there is still a need to develop representative office infrastructure. Meanwhile understanding of the requirements that must be completed in submitting infrastructure development proposals still needs attention.

d. Program Implementation on the land governance:

Constraints faced in implementing the land management program include, among others, the internal and external implementation rules and related to financing and authority. To carry out agrarian reform, the handling of neglected land, the handling of disputes, conflicts and land cases and the legalization of assets need more intensive attention.

\section{Legal Basis}

Article $18 \mathrm{~b}$ point (2) confirms that the State recognizes indigenous peoples' units and traditional rights as long as they are still alive and in accordance with the development of the community and in accordance with the principles of the unitary state of the Indonesian republic. In line with the above norms, Article 33 paragraph (3) of the Constitution of 1945 also emphasizes that the Earth, Water and Natural Resources contained in the state are used for the greater good of the entire Indonesian people.

Further, Phase 33 above, followed by the birth of Law No. 5 of 1965 on the Agrarian Laws, which Article 2 explicitly states that under the provisions of section 33 paragraph 3 of the Constitution and matters as referred to in Article 1, the water and space, including the natural resources contained therein are at the highest level controlled by the State, as the whole organization of the people.

Among the mandates contained in the meaning of the right to control the state, Article 2 paragraph (4) of the UPA states that the right of domination of the State upon its implementation can be conferred on the Swatantra and customary law societies, as necessary and against national interests, in accordance with the provisions of the Government Regulations

In the context of establishing the national agrarian law system, Article 5 UUPA also emphasized that agrarian law applicable to earth, water and space is a customary law, as long as it does not conflict with national and State interests, based on national unity, with Indonesian socialism and with the rules set forth in this law and other laws, all with regard to the elements that depend on religious law.

According to some constitutional norms and the lower level norms in the above agrarian law can be taken into account the following key points:

1. Underlining the concept of the right to control the state and its elaboration in the field of land and land materially and formally into statutory regulations

2. Giving a mandate to establish a national agrarian legal system

3. Putting the National Agrarian Law Spirit should be based on customary law as the original law of the Indonesian people

4. Giving a mandate for a comprehensive translation into derivative legal products, national diagram institutions and a clearer system for administering agrarian and land matters into the government system.

The agrarian legal system since its birth which is more systematic based on the LoGA began to be independent in understanding the material elements of the law that are abstract in the context of the arrangement of subjects, objects, and their rights and 
obligations are clear. Likewise, the formal nature of arrangements, namely concrete institutional arrangements concerning how to access land rights and how to resolve disputes, is increasingly clear.

It's just that there are interesting developments along with regime changes, where in the period after independence until before the birth of the new order, the agrarian legal system is regulated in an agrarian legal system integrated with the LoGA as its basic regulation, while the new order regime until now the agrarian system is both material in nature as well as formal implementation through various legal sectors outside the LoGA that are still in the cluster of natural resources, or are attached to other legal and institutional sectors.

5. In principle, the local dispute resolution model based on local wisdom and customary law are recognized and facilitated in the national agrarian legal system and in the general national legal system. It's just that in the implementation it really depends on the legal products at the regional level as well as the village, the existence of the customary land law of the local community, the life of the existing customary institutions and the existence of the adat community leaders.

As affirmed in Article 5 of the BAL, National Agrarian Law is based on customary law by heeding religious elements. Likewise regarding its nature, Indonesian agrarian law is formal supported by the existence of another national legal system as an example of the Judicial Power Law, which recognizes and respects customary law by excavating living law that lives in the community through prioritized peace procedures. Furthermore, various natural resource sector laws recognize the existence of indigenous peoples.

The development of national law as stated in Program Pembangunan Nasional (Propenas), in Rencana Pembangunan Jangka Menengah
(RPJM) and Rencana Program Jangka Panjang (RPJP) emphasizes the development of a legal system based on indigenous peoples.

\section{Principles}

a. The concept of land as dual ownership God-Human being

b. Recognition of individual rights insofar as they do not prejudice communal interests

c. Maintaining the sustainability of the ecosystem

d. Togetherness

e. Maintain social ties

f. Stick to culture and tradition strongly

g. Compliance is based on the awareness of the parties to customary law procedures

h. Respect for community leaders (adat) as trusted leaders

2. Basic Concept of Dispute Resolution based on the Palace of the Court are as follows:

a. The king as a symbol of the highest ruler of the land and the integrity of the community and also community leaders who should be role models of society.

b. Pay attention to the rights of collectivity

c. Magical transcendental

d. Gradually recognize individual ownership

e. Simple and dynamic law

f. The strategic role of community leaders and courtiers as a representation of the role of the kingdom.

\section{The Work Procedure Model for Dispute Resolution}

The model of land dispute resolution based on local wisdom is essentially a form of output from instrumentalization which is part of the process of institutionalizing customary land systems. This model was developed from the values of the customary 
land administration system concept. The existence of law and society in the view of customary law is an inseparable unit. Law and society undergo an evolutionary process simultaneously so that each sub-system of law and sub-system of society is able to perform its functions optimally. The existence of a gab gapbetween the two makes there an imbalance between das sollen (supposedly) and das sein.

The colonial legal system that dictated the existence of written western law and written customary law had consequences for the development of an imbalanced national legal system. This has an impact on the gap in the achievement of objectives and legal ideals that differ greatly between rural indigenous communities, as well as agricultural lifestyles with migrant, urban, migrant communities. The more prosperous western pattern representation society is side by side with the eastern pattern representation society.

a. The element of representation of the right to control the state as a reflection of the right of the king's authority.

Every unit of society is in need of the highest organizational element that is authoritative and intertwined. The highest organization in adat (customary) community is the adat community represented by the adat leader. Representation of the State's Right to control so that the model of land dispute resolution works effectively that the state's right to control must be spelled out within the limits of the rights and obligations of the state which are just, certain and beneficial to the community. The State Right also covers authorities on the arrangements regarding objects, subjects, relations between subjects and objects and other restrictions between public and private interests.

In the context of the dispute resolution model based on regional cultural wisdom, the regional chairperson, the king, or the adat leader act as police makers in such a way that the highest organizational authority continues to occur and will effectively become a resolution of land conflicts.

b. The cohesiveness of social rights and public interests above individual interests

Public interest which accommodates all parties. The social ties that make the community prosperous include the implementation of the public interest. The public interest can at a macro level cover and at least provide equal opportunities without discrimination for the achievement of family and individual interests. Therefore, the condition of the state in achieving the public interest will be corrective to the effectiveness of the dispute-based dispute resolution model.

c. Religiosity and multi-dimensional understanding above land ownership awareness;

The effectiveness of the legal method is closely related to other regions. Each method has its own strengths and weaknesses. The religious method in the field is reflected in the level of religiosity of the rules and behavior and habits of government administration by community leaders. The traditionality of adat organizations gives a positive correlation to the authority of government organizations and their apparatuses, thereby affecting the effectiveness of dispute resolution. Obedience of community leaders increases the integrity and trust of the people.

d. Recognition and respect for individual rights to other individual rights

A fair and real balance of individual interests and the public interest reflects the existence of the maturity of culture and the structure of law and state. Translation into technical legal products and into the level of understanding of the legal apparatus in the community is highly correlated positively with the settlement of land disputes based on customary values. 
Fundamental factors do influenc the effectiveness of the organizational performance of Land Dispute Resolution

1. Dynamic legal institution

Institution is a unit of duties and roles following a work system which is contained in a particular body unit that is played by the apparatus or person assigned to it. A dynamic institution is an institutional element that is responsive to the complexity of the demands of the development of society.

Institutional settlement of land disputes based on regional values and local culture which is the basis of support is based on dynamic legal products, simple settlement procedures according to the level of community legal awareness, as well as the qualification system of the apparatus or people who carry out the integrity and trust of the community.

2. The active role of community leaders Customary value-based dispute resolution models need to be supported by complex qualification systems, more than just qualifications as certain professions, but combined with formal and informal track record qualifications that demonstrate the ability to lead and high public trust and are able to provide concrete solutions to problems in society.

The dispute resolution model is based on regional values, the active role of community leaders who are responsible for making this model unique and superior with the support of traditional institutional structures and culture.

\section{Projection of New Design of Agrarian Conflict Resolution}

\section{a. Agrarian Court}

Philosophically, juridically as well as, the idea of an agrarian justice does not suppose. It's just that the institutional picture of academics has never been conceived in detail. This research will parse the agrarian justice model based on good land governance in academic exploration. The substantive devices of agrarian justice from vision - mission to procedural law are very urgent to put forward.

\section{b. Alternative Resolution for Agrarian Conflict}

Alternatif Resolution on the Agrarian Conflicts is a mandatory mission as regulated by Tap MPR No $I X / 2001$. This method can be an integral part of agrarian justice or separate. However, the elaboration of substantive tools in resolving alternative agrarian conflicts needs to be explored so that they offer practical and effective agrarian conflict resolution models.

\section{E. Conclusion and Future Direction}

1. Conclusion

a. The current legal and institutional system for resolving land disputes are less compatible with the nature of Indonesian legal consciousness. Actually, there are statutory provisions in the natural resource and land sector which regulate the resolution of land disputes, as well as the constitutional provisions of Article 18 of the 1945 Constitution and Article 5 of the BAL ( Basic Agrarian Law No. 5/1960) concerning recognition of indigenous peoples and all rights, but the elaboration and institutionalization of their values is further still less than enough.

b. Failure factors are derived from legal products that have not been responsive to the demands and levels of public legal awareness, institutional factors that are based on colonial inheritance values, sectoral and secular capabilities, as well as system procedures for settlement models that are formalistic, bureaucratic, and costs that are not 
affordable. The gap factor in the legal awareness of government officials and community legal awareness due to different system values.

c. The development of a legal system model based on local wisdom is nothing but a legal system that starts from the value of the original Indonesian legal system. Indonesia's customary legal system relies on concept of fairness, certainty and authority from the highest organization of power units manifested in the concept of the right to control the state; the concept of religiosity, magical and transcendental, the concept of cohesiveness in the administration of public interests balances the implementation of the fulfillment of individual interests over the control of land rights, the value of simplicity and dynamism in the customary institutional system of resolving land disputes; active role of community leaders and community participation in the resolution of land disputes

\section{Future Direction}

In responding the current problems of agrarian disputes resolution, there are some future directions that should be noted. They are as follows:

a. Strengthening national agrarian institutional reforms

b. Sufficient excavation and institutionalization of original Indonesian law

c. Empowerment of the mastery of community rights in all regions in Indonesia as well as an increase in synergistic community legal awareness by increasing legal awareness in the formal institutional system of government in the region up to the level of village government towards the importance of developing a model of land law based on legal values Indonesian custom

d. Empowerment of regional and customary land institutions

\section{References}

Books and Journal Articles:

Annual Report on Land National Agent. 2015 edisi 1.

Nettheim, G. (2002: 200). ADR for Land Matters

Hakim Garuda Nusantara. 2006. Tanah untuk Rakyat, Paper, International conference, Komnas HAM, p.67

Mahfud, Politik Hukum Indonesia, Gadjah Mada Press, 2000.

Soemardjono, M. (2010). “Hukum Pertanahan, dari Regulasi sampai Implementasi", Kompas Group

(2001). Permasalahan Pertanahan, dari Regulasi sampai Implementasi, Kompas Group. (2010). Hak Sosial Politik Ekonomi Warga dalam Pertanahan, Kompas Group.

Martin, J. \& Turner, C. (2004) Unlocking Law, Judith Bray, Series editors.

Nur Fauzi, N. (2000). Pembaharuan Agraria, 2000. KPA.

Soerjono Soekanto, S. (1999). Penelitian Sosial Djambatan press

\section{Regulations:}

Alain Marciano, 2009, Law and Economics, A. Reader, . Publisher: Routledge, London and New York.

Basic Agrarian Law No. 5/1960

Law No. 11 of 1974

Law No. 14 of 1970

Law No. 2 of 2012

Law No. 30 of 1999

Law No. 4 of 2004

Law No. 4 of 2009

Law No. 41 of 2009 
Law No. 48 of 2009

Law No. 5 of 1960

Law No. 52 of 1960

Law No.20 of 1961

PP 1 of 2014, $2^{\text {nd }}$ Amendment

PP 23 of 2010, Implementation of the Mining Law
PP 24 of 2011, 1 ${ }^{\text {st }}$ Amendment

Presidential Regulation No. 10/2006

The Government Regulation No. 24/97 Land Registration

The Government Regulation No. 60 of 1996 Regarding Land Use 